Vol. 7, No. 1, 2020

https://doi.org/10.23939/eem2020.01.063

UDC 657.01:3(091):330.8(4/9)《18/19» JEL Clasification Code:M41, B15,N01

O. Lemishovska

Lviv Polytechnic National University, Ukraine, $\mathrm{PhD}$, Associate Professor e-mail: leslem@ukr.net

\title{
ACCOUNTING BALANCE AS A HISTORICAL CATEGORY: THE CONTRIBUTION OF SCIENTISTS TO THE HALICY OF THE SECOND HALF OF THE XIX- FIRST HALF OF THE XX CENTURY IN THE DEVELOPMENT OF BALANCE SCIENCE
}

\begin{abstract}
The origins and the evolution of the balance sheet in the system of theoretical and conceptual foundations of balance theories are considered. The researches of scientists of Galicia of the second half of XIX - first half of XX century are analyzed. the accounting paradigms they have formed and theoretical developments with a view to their contribution to improving the balance sheet structure. The hypothesis of this study is the assumption that the period of individual ideas for the development of balance science and relevant methodological approaches that can objectively be used as a means of enhancing the validity of contemporary research. The scientific validity of the proposed use of ideas formed in the past in the designated territory is based on the following postulates: proposals for improving the balance sheet at the expense of past experience in the principles of valuation of balance sheet items and the introduction of the methodological principles of capital structuring formulated in the past (balance sheet liability). These approaches are justified in line with contemporary financial management paradigms, including sustainable development management concepts. The scientific novelty of the study is that for the first time in historiography, objective data on the contribution of Galicia's scientists to the global development of balance science are presented, and suggestions have been made as to the possibility of using certain developments to deepen modern principles and approaches to improving the form of balance generalization.
\end{abstract}

The methodology of the study is based on the principles of historicism, scientificity, verification, authoritative objectivity, moderate narrative constructivism. Using general scientific and interdisciplinary methods of cognition, conceptual and methodological developments of Western Ukrainian scientists in the field of balance studies in the period declared by the study were evaluated. Systematic methodology is ensured by the coherent use of general scientific (analysis, synthesis, generalization), historical (historical-genetic, historicalsystem) methods and the application of specific tools for the subject area of knowledge.

Key words: financial statements, balance sheet, balance theory, asset and liability balance, the theory of balance of the territory of Galicia, conceptual and methodological works of Western Ukrainian scientists.

\section{Introduction}

The development of accounting thought and accounting theory have always been closely linked to the form of balance sheet, which, forming a projection on the functional content of accounting, served as a source of meaning and terminology. The accounting information is subordinated to the general purpose of providing reliable and relevant data on the financial and economic status (potential) and performance of the economic entity. From the point of view of the informative nature of the public reporting of modern market economy entities, there is an insufficient elaboration of an adequate concept of balance modeling, principles and methods of evaluating balance sheet items.

At present, there is a total and growing distrust of participants in business relations, where one of the multifaceted problems is the lack of efficiency of the institutions of formal control over the objectivity (reliability) of public financial information. In today's business relations, there is a 


\section{O. Lemishovska}

need for confidence that financial and economic agreements are formed in conditions of sufficient informativeness of participants, which aggravates the problems of quality of public reporting and in particular balance. The standardized reporting information array is essentially the only (in terms of sufficient reliability) available and regularly updated enterprise data set.

There is a large amount of research available today research on an international scale confirms the dissatisfaction with the relevance and usefulness information of public financial reporting. For example, well-known financial reporting specialist, finance and accounting professor at Stern Business Schol (New York University) Baruch Lev, considers the "failure of accounting standards developers to adopt a traditional income statement (compliance) model in favor of a balance sheet model (asset valuation)" [1]. That is, it is the highest, in the view of this and many other scholars, the potential formulated in the past for the concept of accounting. Such a concept was developed in the course of the long evolution of the balance theories and the efforts of the leading scientists of European countries. The above actualizes the need for a more in-depth study of the proposed ideas during the development of balance studies. Balance in public reporting is the core, quintessence of reporting data, however, despite the centuries-old experience (theory and practice) of drawing up the balance, the problem of ensuring the quality of its information content remains relevant.

\section{Formulation of the problem}

Modern scholars are of the opinion that historical "balance sheet research is relevant today" [2, p. 138], whereas "the generalization of the development of the historical aspects of the balance sheet provides an opportunity to understand its current meaning, to assess the present state of construction and to identify problems for the further development of the balance sheet" [3]. It is believed that the results of such studies provide an objective way of predicting the direction of further evolution of this major form of public financial reporting [4].

In thematic historiographical sources, studies of the evolution of balance focus on the stage of development of balance thought, which occurred in the second half of the XIX - mid-twentieth centuries. During this period, "balance studies" for the first time went beyond the scientific debate and its theoretically formed forms began to be reflected in the legislative provisions in the field of accounting and public financial reporting of different countries. Of course, the balance theories outlined in the accounting historiography of the three "S", articulated by the initial letters of their developers - Simon (1886), Schmalenbach (1919) and Smidt (1921) [5-7] came to the fore. These are representatives of the German School of Accountancy, which was the basis for theoretical studies in Austria-Hungary and, accordingly, in the territory of Galicia. The work of scholars of the German School of Accountancy and European studies in the field of balance studies were well known in the scientific circles of Galician scientists. Forming their own theories and paradigms, some of which are classified at the "international level", Galicia's scholars relied on these works.

The high status level of workings of Galician scientists is confirmed by the findings of some domestic and foreign researchers. Some of them point to the development of another, in addition to the three above-mentioned balance theories, the "econometric balance theory" [8]. This is the development of P. Ciompa [9] was considered at the International Accounting Congress, which testifies to its high scientific level and contribution to the global development of accounting theory. ["Congres international de comptabilite, de droit commercial et comptable" "Compte-Rendu, Lyon1908"].

Actualizing the unexplored problem of the publication of the contribution of Galician scholars to the world heritage of the development of balance studies, we will conclude, above all, foreign scientists. For example, Polish researcher Biadacz R. points out that "by his development R. Ciompa made a significant contribution to the theory of accounting at the turn of the nineteenth and twentieth centuries, in which he outlined the econometric balance theory: it was recognized as a sensational scientific discovery in this field on a scale II [10]. In a similar way this development was characterized by the French scientist Karl-Friedrich Israel. Assessing the theoretical structure of this 
theory from the point of view of the formulated econometric concept of balance generalization, compared to the principles of modern econometric concepts, he noted: "I have come to the conclusion that modern econometrics must return (to be restored) to its descriptive character, defined by R. Ciompa [11]. Finally, the justification that, by its theoretical and methodological level, the development of this scientist is one of the most extraordinary and at the same time intellectual works in the field of accounting and has introduced a new impetus to the global development of balance studies is deeply revealed in other author's publication [12].

In addition to the above, a high level of scientific and methodological character was observed in other works of Galician scholars in the field of balance studies. This conclusion can be justified, for example, on the basis of the development of the Balance Sheet. Studja ekonomiki prywatnej (Góra W., 1920) [13], Rachunkowość pojedyńcza i podwójna (Lenkiewicz W., 1905) [14], Polskie bilansoznawstwo (Seifetr T., 1930) [15], Wartość w economice a w bilansach (Tomanek F., 1931) [16]. The last author was a leading specialist at the regional level in accounting and balance. His development, aimed at justifying the basic principles of "balance studies", has been widely discussed. For example, it was the topic of his "inaugural" speech at the School of International Trade at the International Conference "Economic Life and Social Economy" held by the Polish Economic Society in Lviv [16] and at an in-depth level was disclosed in a summary presentation at the 1st Regional Congress of Accountants of the Lviv District "Reconstruction of Economic Life and Accounting" [17].

Given the above and a number of other factors, "there is a need to study the history of accounting (financial) reporting in Ukraine, since the issues of its formation and evolution are poorly understood [18, p. 443, 444].

\section{Methodological approach}

The methodology of the article is based on methods of scientific knowledge such as general scientific and special. The choice of research methods is determined by the subject matter and the intended purpose of this article. The developed methodology provides objectivity of disclosure of various scientific and applied researches of scientists of Galicia for improvement of balance generalization. To assess the accounting developments under study from the point of view of the analysis of publications of foreign and domestic researchers on the current contemporary problem in the field of balance generalization, the results and conclusions of research sources of historiographic nature, which revealed a rational solution to such problems. The chosen method has allowed to get new results concerning previously unexplored works of the theorists and practitioners of Galicia, to get a more extensive information base on their contribution to the world development of balance studies.

The process of analyzing and evaluating conceptual foundations in the researched of Western Ukrainian scientists was ensured by the use methods such as formal logic, retrospective method, interdisciplinary methods. The determined coordinates of the study determine the use of a systematic methodological techniques, in which the systemhistorical method is the basic toolkit. The research used scientific-cognitive methods of abstraction and concretization, which provided the opportunity to borrow experience of conducting studies of this type. For the theoretically and methodologically clarify the processes of formation and evolution of contemporary approaches to balance have been used the method of historiographic analysis and the historicalcomparative method.

Through the integrated use of the above methods, historical and accounting intelligence was carried out in accordance with the principles and approaches of the JEL Code Classification.

\section{The purpose of the article}

The unresolved problem to date is to consider the lack of systematic and professionally oriented research of Galicia's theorists in the field of balance in the historical past, to put into scientific circulation the results obtained by them and to substantiate the possibilities of using individual ideas for the modern processes of improving and improving.

\section{Analysis of the latest pulication}

Studies of the history of the balance sheet were conducted by many domestic and foreign scholars in the context of numerous scientific schools, currents, directions, periods, as well as from a specific point of view regarding the 


\section{O. Lemishovska}

formation and development of balance sheet generalization through the prism of its consideration as accounting and economic category; meaningful content and functional positioning of the balance generalization, incl. and within specific accounting models. Some studies also have a purely specific (narrowed) nature of the historical excursion, including a comparative consideration of the legal, economic, procedural and personal dominant component in different approaches during the evolution of the balance sheet. However, as K. Y. Tsygankov concludes "the historical balance form, like all its reformations, has not received a detailed theoretical interpretation" [19, p. 18].

Regarding the disclosure of the content and analysis of the developments in the time period of the regional section declared in the article, these developments are characterized only partially. For example, a full member of the International Academy of Accounting Historians, well-known Russian scientist Y. V. Sokolov stated: "in Austro-Hungary R. Ciompa expanded accounting theory by enriching its techniques of algebra and geometry, resulting in world science qualitatively" [20, p. 325]. In the section "Balance sheet development" of the monograph [21], A. V. Chizhevskaya points out: "Among the works devoted to accounting, we consider the development of P. Ciompa, where particular attention was paid to the objectification of the balance sheet items - the presentation of the real (really existing, not impaired) value of property and capital" [21, p. 151]

L. Pilipenko articulates the development of Lviv economist R. Ciompa such that by all scientific criteria should be recognized as another model in accounting theory and gain a prominent place among the above static, dynamic and organic balance theories [8, p. 64].

The purpose of the article is to systematize knowledge about the contributions of Galician scientists to the development of the balance sheet generalization, formulate specific conclusions about the importance of such developments and make proposals for the possibility of using individual studies for the development of modern forms of balance.

\section{Presentation of basic material of the research}

The topic of balance summarization is one of the most common in the field of historical studies of the evolution of accounting. In historiography, it is customary to distinguish the conditional stages of the development of the balance sheet (the construction of forms and content of articles) - the emergence of balance as an economic category, the formation of balance as an accounting category and the stage of theoretical and scientific development in the field of balance and reporting (balance theories and accounting models).

The whole range of studies of the origins and evolution of the balance sheet generalization of accounting data is predominantly based on the principles of evaluating its practical construction and theoretical constructions of the basic ones. Historiography in the subject area of knowledge adheres to the view that, in the initial stages of the formation of system accounting and in the subsequent stages of its development, the balance was formed in an arbitrary form and used as a means of control and management of trade or banking. At that time, the practice of conducting accounting analytical accounts without a proper methodology for their synthesis caused an overload of articles of any of the forms of balance sheet generalization used. Despite this, some scholars hold that "historical balance was the technical form of capital balance" [19, c. 21]. These views are based on the fact that the "capital account" (or the main balance sheet general account) was "tied" to the so-called "inventory" (description of valuation property) in accounting practice. On the basis of correlation of such account with property accounts and debt accounts, a balance sheet document of a certain form was formed, which nevertheless made it possible to outline with greater or lesser degree of certainty the financial status of the enterprise.

Summarizing the accounting information in the current accounts was a common approach to drawing up a balance sheet, which, in essence, amounted to an elementary transfer of arithmetically determined balances to a consolidated balance sheet. For example, an analysis of archival documents containing the preserved balance sheets of economic entities in the territory of Galicia and current accounting and accounting documents for the period defined in the article shows that this approach was used until the first half of the XIX century. Based on these archival sources and materials of the manuals of theoretical 
orientation of East Gothic theorists to the middle of the XIX century. it is sometimes difficult to establish specific distinctive features of the concepts of capital and balance. Only in subsequent periods is there a noticeable delineation of these concepts and their interrelation. This was due to the fact that a balancing account of "capital" was introduced into the consolidated dataset of property and debts. This practice of drawing up a balance sheet has been well-established in Europe and has been borrowed from Austro-Hungarian enterprises (and Galicia, respectively). Subsequently, this arbitrary practice received, although quite "blurred", however, the legislative consolidation.

The further development of the balance sheet in Galicia took place in the same way as in other European countries. That is, improving the format of the balance based on practical demand and regulatory regulation, as well as through the influence of developed theories (paradigms) of accounting and balance. The latter trend was associated with the need for a clearer form of balance sheet for joint stock companies, since in accordance with the regulations on companies, the requirement to publish their reports and balances was made by them. Under Austrian law, the balance sheets of joint-stock companies and similar cooperative associations were to include data on fixed and reserve capital, net income and depreciation of fixed assets, as well as the costs of their creation (organizational funds). That is, the legislation at the time approved the balance sheet as a reporting form that reflected in it articles that could not be formed solely on the basis of inventory data.

Regular compilation and publication of balance sheets by joint stock companies of insufficiently specified content at the end of the 19th century. eliminated the need for clearer rules for its construction, eliminating the possibility of reporting in a more attractive form through methodological manipulation. Historiographic sources indicate that such manipulations were manifestly reflected in the chosen approaches to property valuation, as well as in the use of methodological tools - manipulation of income (loss) and capital accounts, opening of accounts or processes of depreciation. For this reason, balance remained, though an important object of practical accounting, but at the same time became the subject of theorists.
Balance as a reporting public form received a higher level of formalization in the period of balance sheet formation (the science of the economic essence of the balance sheet, the principles of its construction, rules for the recognition and evaluation of its items). The basis of this accounting direction were the teachings of I. F. Shera (1890), in which he laid the basis of accounting and developed a theory of accounting, called the balance sheet [22]. Within this direction, several specific balance theories have been formed, which, in their conceptual and methodological basis, nevertheless differed from one another. For example, dynamic balance theory [6] focused on determining the fair value of financial results that requires an assessment of property values at purchase prices rather than real current values Using such an estimate distorts the total value of assets at the time of the balance sheet. To overcome this problem in organic balance theory [7] proposed to evaluate assets at current prices, introducing the concept of "reproductive value of the enterprise". Dualism (the real value of financial assets and the reliability of the indicator "productive activity of the enterprise") by the author of this theory was eliminated by his proposed method of comparing the reproductive value for the reporting period. The difference in the total value of the assets was the profit of the enterprise. Static balance theory [5] had a "legal leaning" and was focused on the settlement of insolvency and bankruptcy. Its important aspect was the orientation of the balance sheet to reflect the assets and liabilities at current prices..

Assessing the content of these balance theories, well-known modern German scientist Jorg Baetge concludes that they based on simplification and aggregation (objectification) formulated proposals for the balance, which in its content only declaratively shows the balance value of the property condition of the organization. He noted that the balance sheet theories of all the components of the enterprise value are not taken into account, and on this basis it is concluded that no balance theory can be achieved in the balance sheet of the real value of the enterprise capital capital, since they are based on the principles of individual valuation. [23, c. 13]. During the period of balance studies development, East Gothic theorists also criticized the problematic components of balance theories. For example, 


\section{O. Lemishovska}

R. Ciompa (1910) gave a similar assessment of approaches to balance sheet construction: "today they have gone so far that the accountant feels sufficiently authoritative to" conjure up "property values (assets) and values of components of capital (total capital)" [9].

In the global space, balance studies were also formed in the context of separate accounting schools with different basic principles: Italian logismographic and statmographic approach; French - mathematical; Anglo-American pragmatic; German - Chamber. In the territory of Galicia the basic provisions of the German school of accounting were dominant, but in their theoretical developments they used both the work of representatives of this school and the European heritage. In addition, the orientalist theorists' development orientation was influenced by practical approaches to building the balance sheet used by foreign firms operating in the area. Based on archival documents [24], first let's point to some big companies: "Malopolska" - Koncern francuskich towarzystw naftowych, pemyslowych I handlowych we Lwowie; Polsko-wloska spylka akcijna dla przemyslu naftowego "Bonariwa" we Lwowie; "Austria". Petroleum-IndustrieAktiengesellschaff in Wien-Towarzystwo akcijne dla przemyslu naftowego w Wiedniu; Holendersky syndykat naftowy. Spulka z ograniczonoj odpowiedzialnosci we Lwowie). The balance sheets of these corporations show that one of them (Italian) was dominated by the balance of the gross (consisted of indicating retained earnings), in others - the balance-of-net (consisted of taking into account the distribution of profits). However, a technical and procedural view prevailed in the region, recognizing the balance as "a synthesis of off-balance sheet accounts".

Revealing the general landscape of theoretical and applied developments in Galicia concerning the solution of problems of objectification of the methods of balance generalization, we say that the basis for the development of scientists of the land was the "Encyclopedia of Accounting" Roberta Sterna. The starting point for establishing the bookkeeping value of the enterprise was the postulate that "only property that possesses the capacity and purpose of productivity is capital" [25, c. 290] . Another basic development was the work of Richard Reisch, Klemens Kreibig "Balance and tax", where under the property values was presented "the totality of all tangible and intangible assets available to the accountant" [26, c. 1]. The work presented and the paradigms offered have argued in various ways the appropriateness of using the principle of subjectivity in valuing assets for accounting purposes. It was argued that each item should be valued according to the principles that are most appropriate for a particular group of assets. It was on the basis of the above doctrines that the objective expression of the value of capital was substantiated.

Both the common European practice of that time and Galicia's enterprises were dominated by the technique of calculating the so-called "net capital" (the main object of the annual report is the residual capital of the owners). Such an indicator was inherently comparable (identical in meaningful sense) with the insertion of a summary financial result. Methodologically, it was determined by simple arithmetic subtraction from the amount of assets of indebtedness to third parties. This basic basis was also observed in the scientific paradigms of Galician scholars: "assets minus foreign capital give the amount of equity". This way of establishing the value of capital they articulated "recapitalization" [27, c. 15].

It was a common experience, if not sufficiently focused from a theoretical and methodological point of view, but recognized as a method of indirectly presenting in the public accounts the productive activities of the enterprises of that time. It should be noted that this technical and procedural methodology, by its very nature, still coincides with the basic approaches to reporting in some UK companies. On the basis of the developments of leading European scientists, as well as individual achievements in the financial and accounting sphere of the country, knowledge about the essence of the balance method was deepened, the rules for evaluating the balance sheet items were formalized, and the form, content and structure of the balance sheet.

The development of advanced forms of balance sheets was carried out in two directions balances for small business entities (a prototype of modern simplified reporting for small businesses) 
Accounting balance as a historical category: the contribution of scientists to the halicy...

and balances for large enterprises and joint stock companies. However, in both cases, the development was based on the proposition that "the balance indicates the ultimate estate status of the enterprise through material and ideal values ... capital is the determination of the value of the estate" [28, c.14]

In the table. 1 for an example is given in the original statement formulated in the writings of
Galle Ja [29] Tomanek [16] property balances (property balances). These forms of property balances, which are proposed by other Western Ukrainian researchers, look visually simplified. However, the justifications for the developed format and content of the articles of the balance sheet generalized numerous arguments, and for their practical application suggested methodological provisions.

Table 1

Forms and structure of property balance, developed by the theorists of Galicia

\begin{tabular}{|c|c|c|c|c|c|}
\hline \multicolumn{6}{|c|}{ Author and the name of work } \\
\hline \multicolumn{4}{|c|}{$\begin{array}{l}\text { Galle Ja. (1938). Zarys ksiegowosti kupieckij } \\
{[29, \text { s. 76]. }}\end{array}$} & \multirow{2}{*}{\multicolumn{2}{|c|}{$\begin{array}{l}\text { Tomanek, F. (1932). Wartość w economice a w } \\
\text { bilansach }[16, \text { s. 79] } \\
\text { Bilanz majakow }\end{array}$}} \\
\hline \multicolumn{4}{|c|}{ Bialans majatkowy } & & \\
\hline & Aktywa & & Pasywa & \multicolumn{2}{|c|}{\begin{tabular}{|l|l} 
Stan czynny & Stan bierny \\
\end{tabular}} \\
\hline 1 & Kasa & 1 & Akcepty & \multirow{7}{*}{$\begin{array}{l}\text { I. Konta czysto } \\
\text { zapasowe: } \\
\text { 1) kasy, } \\
\text { 2) remes, } \\
\text { 3) dłużników. } \\
\text { II. Konta zapasowo- } \\
\text { wynikowe: } \\
\text { 1) towarów, } \\
\text { 2) walut, } \\
\text { 3) dewiz, } \\
\text { 4) papierów } \\
\text { wartościowych, } \\
\text { 5) sklepu, } \\
\text { 6) ruchomości, } \\
\text { 7) nieruchomości. }\end{array}$} & \multirow{7}{*}{$\begin{array}{l}\text { I. Konto własnego } \\
\text { kapitału. } \\
\text { II. Konto obcych } \\
\text { kapitałów: } \\
\text { 1) trat, } \\
\text { 2) wierzycieli, } \\
\text { 3) pożyczek } \\
\text { hipotecznych. } \\
\text { III. Konta wynikowe: } \\
\text { 1) odsetek, } \\
\text { 2) prowizji, } \\
\text { 3) koszów. }\end{array}$} \\
\hline 2 & Towary & 2 & Wierzyciele & & \\
\hline 3 & Weksle & 3 & Kapitał Jana & & \\
\hline 4 & Dłużnicy & & Kosowskiego & & \\
\hline 5 & $\begin{array}{l}\text { R-k prywatny } \\
\text { Jana Kosowskiego }\end{array}$ & 4 & $\begin{array}{l}\text { Kapitał Witolda } \\
\text { Kosowskiego }\end{array}$ & & \\
\hline 6 & $\begin{array}{l}\text { R-k pryw. } \\
\text { Witolda } \\
\text { Kosowskiego }\end{array}$ & 5 & Czysty zysk & & \\
\hline 7 & Ruchomości & & & & \\
\hline
\end{tabular}

The analysis of developments in this area shows that in almost all works, the emphasis was placed on the importance of the stage of recognition of assets (assets) and the importance of inventory for the accuracy of balance sheet data. For example, in the work Sciborski A. [30] in the section "Recognition of property" (in the original statement Rozdział I Rozpoznanie majątku Inwentowanie) and in the section "Spisanie majątku czyli sporządzenie inwentarza: use of prowadzenia inwentarza results when completing the balance sheet. A similar rationale for the reciprocal impact of inventory results and balance sheet data can be found in the development of Galle Ja [29] in the highlighted section "Inwentarz i bilans majątkowy".

We will highlight separately the important, in our view, aspects in the development of an improved form of balance. In particular, the emphasis in particular developments on such criteria components as the marking of property assets (definition and description of individual assets). This component at a high research level was developed [30] and with sufficiently high methodological support is given in the section "Oznaczenie właściwości majątku: Oznaczenie i opisanie individualsynczych części składowych majątku; Oszacowanie majątku". Similar 


\section{O. Lemishovska}

conceptual and methodological content and nature of approaches to the structural description of property ownership are given in the works of Lenkiewicz W. [14] and the development of Seifetr T. [15] and Au Juliusz [31].

In some developments such concepts as "active property" and "passive property" stood out. This can be seen both from the report form presented in the table by Tomanek F., and from the justifications given in the section "Oznaczenie ilości majątku: Majątku czynnego; Majątku biernego" in work [30].

The types of balance generalization were distinguished in the developments. For example, in the work of Corniak S. [32] the "balance sheet" (Bilans próbny), the "work balance" (Prace bilansowe) and the "general balance" (Bilans abrlaryczny; Bilans kontowy) are highlighted. The most important components of these developments should be considered by the authors formulated a balance sheet method. Let us point to the following approaches to the construction of the method of property balance in work [30] "Bilans majątkowy Sposód sporządzania bilansu majątkowego" and in work [29] - "Bilans zamknięcia i bilans otwarcia". Methodological components of the development are also proposed approaches to establishing changes in property ownership - "Zmiany majątkowe: O zapisywaniu zmian zaszlych $\mathrm{w}$ stanie majątku i

prowadzeniu w tun celu rachunków" [30] and property control - "Kontrola stanu majątkowego przedsiębiorstwa" [29]. The application in practice of the proposed components to the construction of balance sheets can be seen from the promulgated balance sheets of cooperatives that were members of the Audit Union of Ukrainian Cooperatives in Lviv [33].

In developing the conceptual and methodological principles of balance sheet generalization for public companies, the existing problems were comprehensively analyzed: "our balance sheets are somewhat unclear, since in many cases it is simply not possible to find out the significance of all the articles, especially when reserve funds, reserves and so-called balances are found in the balance sheet. mutual test scores" [9]. Specific shortcomings of the balance sheet reports at that time were presented, substantiating them inaccurate or incorrect (false balances). From the table. 2 shows that the standard form of the balance sheet of that time (Eine falshe Bilanz) was based on its own research, and in a comparative variant the format of the advanced balance sheet generalization (Eine richtige Bilanz) was proposed. Note that the improved construction of balance sheets, formulated in the works [9] and [13] nevertheless, they differ significantly both in conceptual content and structural structure.

Table 2

The common and proposed forms of balance in the development of Eastern Gothic scholars

\begin{tabular}{|c|c|c|c|}
\hline \multicolumn{4}{|c|}{ Ciompa, P. (1910). Grundrisse einer öekonometrie ... natürliche theorie der buchhaltung;[9, s.186] } \\
\hline \multicolumn{2}{|c|}{ Eine falsche Bilanz } & \multicolumn{2}{|c|}{ Eine richtige Bilanz } \\
\hline Aktiva & Passiva & Vermögen & Kapitalien \\
\hline 1 & 2 & 3 & 4 \\
\hline Bargeld & Stammkapital & Bargeld & $\begin{array}{l}\text { Beamtenu. Arbeiter: } \\
\text { Gehalte, Löhne }\end{array}$ \\
\hline Münzen & Reservefonds & Münzen: angekauft & Akzepte: nominale \\
\hline Effekten & Dubiosen-Reserve f. Rimessen & Kurs-Verlust & Diskont \\
\hline Effektenzinsen & Dubiosen-Reserve f. Debitoren & wirklicher Wert & wirklicher Wert \\
\hline Rimessen & Kursdifferenzenreserve & Effekten: angekauft & $\begin{array}{l}\text { Rimessenkreditoren: } \\
\text { begeben }\end{array}$ \\
\hline Devisen & Erneuerungsfonds f. Maschinen & Kurs-Gewinn & Diskont \\
\hline Debitoren & $\begin{array}{l}\text { Trapsitorisches-Konto } \\
\text { (Depositen) }\end{array}$ & wirklicher Wert & wirklicher Wert \\
\hline Waren & Akzepte & Effektenzinsen & Kreditoren: Nominale \\
\hline Mobilien & Kreditoren & $\begin{array}{l}\text { Rimessen: im } \\
\text { Portefeuille }\end{array}$ & Diskont \\
\hline
\end{tabular}


Accounting balance as a historical category: the contribution of scientists to the halicy...

Continuation of table 2

\begin{tabular}{|c|c|c|c|}
\hline 1 & 2 & 3 & 4 \\
\hline Maschinen & Nachschüsse & begeben & $\begin{array}{l}\text { Verlustanteil wirkl. } \\
\text { Wert }\end{array}$ \\
\hline Nacrhsdhüsseverpflichtung & Antizipationen & (Dubiosen: keine) & $\begin{array}{l}\text { Rimessendubiosenrese } \\
\text { rve - Kapital }\end{array}$ \\
\hline $\begin{array}{l}\text { Transitorisches-Konto } \\
\text { (Kautionen) }\end{array}$ & Diskont der Rimessen K & Diskont & $\begin{array}{l}\text { Verlustanteil } \\
\text { wirklicher Wert }\end{array}$ \\
\hline Antizipationen: Provision K & Gehalte und Löhne & wirklicher Wert & Reservekapital: \\
\hline Diskont der Akzepte & & Devisen: angekauft & Reservefonds \\
\hline \multirow[t]{2}{*}{ Verlust } & & Zinsengewinn & Verlustanteil \\
\hline & & Kursgewinn & wirklicher Wert \\
\hline \multicolumn{2}{|c|}{$\begin{array}{l}\text { Gora W.(1920). Bilanse. } \\
\text { prywatnej }[13, \text { s.176] }\end{array}$} & wirklicher Wert & $\begin{array}{l}\text { Kapitalreserven: bei } \\
\text { Effekten }\end{array}$ \\
\hline Aktyva & Passywa & Debitoren: Nominale & Devisen \\
\hline Kasa & Kapit ałakcyjny & Dubiosen & Waren \\
\hline Pożyczki hipoteczne & Zwycz. fundusz reserw. & Diskont & Immobilien \\
\hline Weksle & Nadzwycz. fundusz reserwowy & wirklicher Wert & wirklicher Wert \\
\hline Debitorowie & Specjalny fundusz rezerwowy & $\begin{array}{l}\text { Waren: angekauft per } \\
\text { Kassa und } 3 \text { Monate }\end{array}$ & Stammkapital: \\
\hline Udziały konsorcjalne & $4 \%$-owe listy zastawne & Diskont & Verlustanleil \\
\hline Efekta kantoru wymiany & $4 \frac{1}{3} \%$-owe & Gewinn & wirklicher Wert \\
\hline Pożyczki na zastaw efekt & $5 \%$-owe prem. listy zast. & $\begin{array}{l}\text { wirklicher Netlowert } \\
\text { per Kassa }\end{array}$ & Nachschuss- kapital: \\
\hline $\begin{array}{l}\text { Gmach bankowy we } \\
\text { Lwowie }\end{array}$ & $\begin{array}{l}\text { Fundusz umorzenia pożyczek } \\
\text { hipotecznych }\end{array}$ & Mobilien: angekauft & Verpflichtung \\
\hline $\begin{array}{l}\text { Zabudowania i magazyny } \\
\text { filjalne }\end{array}$ & $\begin{array}{l}\text { Asygnaty kasowe wraz z } \\
\text { odsetkami }\end{array}$ & Reparaturen & nicht eingezahlt \\
\hline Nabyte nieruchomości & Kredytorowie & $10 \%$ Amortisation $\mathrm{f}$. & wirklicher Wert \\
\hline Ruchomości & Dyskont werslowy & 6 Jahre & \\
\hline \multirow[t]{9}{*}{ Kasa zaliczkowa } & $\begin{array}{l}\text { Kypony od listów zast. aż do } \\
\text { 31/XII }\end{array}$ & wirklicher Wert & Verlust: \\
\hline & $\begin{array}{l}\text { Fundusz premjowy dla } 5 \%- \\
\text { wych list. zast. }\end{array}$ & Maschinen: angekault & $\begin{array}{l}\text { Rimessendubiosenrese } \\
\text { rve }\end{array}$ \\
\hline & Reserwa podatkowa & Amortisation & Reservefonds \\
\hline & $\begin{array}{l}\text { Wylosowane, zapadłe listy } \\
\text { zastawne }\end{array}$ & wirklicher Wert & Aktienkapital \\
\hline & Niepodjęte dywidendy i kupony & Kaution: fremde & Kreditoren \\
\hline & Czysty zysk & Agenten:f. Provision & wirklicher Verlust \\
\hline & Kurs akcyj & Immobilien: angekauft & \\
\hline & Dywidenda & Wertzuwachs & \\
\hline & w procentach & wirklicher Wert & \\
\hline
\end{tabular}

The developers first of all argued that the right balance should represent the real (productive) tangible and ideal (intangible) values and the objective value of capital, expressed by the energy of productive property. In addition, in some developments it was argued that to refer to the balance sheet instead of the terms "Assets" and "Liabilities" should be used the terms "Property" and "Capital", since any accounts payable from a financial and economic point of view must be recognized as foreign (invested, borrowed, borrowed) capital. 


\section{O. Lemishovska}

At that time, a whole system of capital reservation (see falch Bialanz) was developed, which was mainly implemented in practical accounting. In particular, it was mandatory to create a reserve fund through handicrafts, doubtful reserves for debtors, reserves for a change of course, a fund for the restoration of equipment. However, in the proposed development [9] these reserves are significantly expanded (see correct balance). In particular, the concept of "antizipaziren" (antizipaziren), which in its content envisaged the accounting method of extended provisioning (an action that precedes the onset of real events). Their division into active and passive antisipations is justified; for securities and bills, "reserves of capital", "capital on handicrafts" and some others.

In order to substantiate the proposed balance [9], the importance and the critical opinion of the author to the rules of valuation of different balance sheet articles are formulated first of all. (Die Bedeutung der Bewertung). Improved balance sheet valuation principles are formulated and substantiated (Grundsätze der Bewertung in der Bilanz) and the methodological provisions for the valuation of assets are formulated (Die Bewertung des Vermögens). The same was suggested for the valuation of the company's equity (Die Bewertung einzelner Kapitalien), including and in terms of its components: evaluation of the authorized capital (Die Bewertung des Grundkapitals); estimation of reserve capital (Die Bewertung der Reservekapitalien); valuation of foreign capital (Die Bewertung fremder Kapitalien); estimation of capital reserves (Die Bewertung der Kapitalreserven); assessment of passive expectations (Die Bewertung der PassivAntizipationen).

A comparative analysis of the "wrong" and "proposed" format of the balance sheet "Falsche und richtige Bilanzen" with a focus on producing a caricature of the balance - "Eine Bilanzkarikatur", noting on this basis the shortcomings of the legal regulation of the balance sheets "Kritik der gesetzlichenhen" basis. In order to substantiate the proposed balance, the relationship between its data and the main indicators of the income statement "Das Gewinn- und Verlustkonto", taking into account its key indicators - The calculation of net profit or loss in practice (Die Berechnung des Reingewinnes oder Praxlis) and providing the correct (in the author's view) methodology for calculating net income (Eine richtige Berechnung des Reingewinnes).

\section{Conclusion}

Formulation of further principles and approaches to improving the existing balance sheet is advisable to take into account the results of a systematic study of the history of this accounting category, analysis of developments in the field of balance studies, which will make it possible to reflect the experience of predecessors and take into account their experience in modern theoretical and applied developments. The analysis of individual developments shows that some developments in the historical past can objectively enhance the balance sheet's visibility, make it more informative and real, so that the economic resources and capital of economic entities are more objectively represented. These include the methodology for preparing balance sheets for small businesses, as well as sufficiently substantiated balance sheet items for publicly traded companies, especially those related to the provisioning of fixed assets.

\section{References}

1. Baruch, L. (2018). The deterioration usefulness of financial report information and how to reverse it. [Accounting and Business Research], 48, 5, 465493. Retrieved from <https://doi.org/10.1080/ 00014788.2018.1470138>

2. Kaminska, T. G., Tsaruk, N. G., Ulchak, O. V., Garapko, N.I, Melnik, Z.Yu. (2015). Aktivizatsiya krugooborotu kapitalu: oblikovo-kontrolniy aspekt [Activation of the cycle capital: accounting and control aspect]. Nizhin: Vidavets PP Lisenko M. M. [in Ukrainian].

3. Dovbush, V. I. (2013). Balans pidpriemstva: istoriya viniknennya, rozvitku ta stanovlennya [The balance of the enterprise: history of origin, development and formation]. Naukovopraktichne vidannya "Nezalezhniy AUDITOR" [in Ukrainian].

4. Kulyk, V. A. (2010). Bukhhalterskyi balans: munyle, suchasne, maibutnie [Balance: Past, 
Accounting balance as a historical category: the contribution of scientists to the halicy...

Present and Future]. Poltava: RVV PUET [in Ukraine].

5. Simon, G. (1899). Di Bilalanzen der Uftigenfellitaften. German Veit Simon. Berlin.

6. Schmalenbach, E. (1931). Dynamische Bilanz (Funfte Auflage). G. A. Gloeekner, Verlagsbuchhandlung in Leipzig.

7. Schmidt, F. (1921). Die organische Bilanz im Rahmen der Wirtschaft (zweite, durchgqsehene und erweiterte Auflage). Verlagsbuchaltung in Leipzig: G. A. Gloeckner.

8. Pylypenko, L. M. (2016). Rozvytok kontseptsii pobudovy systemy publichnoi zvitnosti korporatsii $v$ umovakh postindustrialnoi ekonomiky [Development of concepts for building a system of public reporting of corporations in a postindustrial economy]. Lviv: Publishing House of Lviv Polytechnic National University [in Ukrainian].

9. Ciompa, P. (1910). Grundrisse einer öekonometrie und die auf der Nationalökonomie aufgebaute natürliche theorie der buchhaltung; ein auf Grund neuer ökonometrischer Gleichungen erbrachter Beweis, dass alle heutigen Bilanzen falsch dargestellt werden Verlag des Handelsschulvereines in Lemberg. Lemberg: Druck von Artur Goldman in Lemberg.

10. Biadacz, R. (2015) Rachunek zysków $i$ strat $w$ Polsce do 1918 roku, [w:] A. Kamela-Sowińska (red. nauk.), Rachunkowość warta Poznania. Teoria $i$ historia rachunkowości. Poznań: Wydawnictwo Uniwersytetu Ekonomicznego w Poznaniu.

11. Karl-Friedrich, Israel (2016). Pawel Ciompa and the meaning of econometrics: A comparison of two concepts. Document de travail du GRANEM.

12. Lemishovska, O. S. (2018). Pavlo Ciompa (18861914) - Lvivskiy vcheniy u sferi buhgalterskogo obliku ta yogo "Narisi ekonometriyi" (nedoslidzheniI storinki istoriyi) [Pavel ciompa (1886-1914). Lviv scientist in accounting and his "Essays in Econometrics" (unexplored pages of history)]. Istoriya nauki ta bibliografistika. Retrieved from http://inb.dnsgb.com.ua/20181/14.pdf [in Ukrainian].

13. Góra, W. (1920). Bilanse. Studja ekonomiki prywatnej / Witołd Góra. Lwów - Warszawa: Książnica t-wa Nauczycieli szkót wyżsżych.

14. Lenkiewicz, W. (1905). Rachunkowość pojedyńcza i podwójna (dla wiekszej własnosci ziemskiei) / Władizsław Lenkiewicz. Lwów: Drukarnja $i$ litografia Pillera i Spolki.
15. Seifetr, T. (1930). Polskie bilansoznawstwo / Teofil Seifetr . Lwow - Warszawa: Ksiażnica-Atlas, zjednoczone zaklady kartograficzne $i$ wydawnicze tow. naucz. szkol sredn. i wyzsz. SP. AKC.

16. Tomanek, F. (1932). Wartość w economice a $w$ bilansach. Streszezenie wykładu inauguracyjnego, wygłoszonego $w$ dniu 16 pażdziernika 1932 r. $w$ wyższej szkole handlu zagranicznego we Lwowie. Odbitka z ksieggi zbiorowej p.t.: „Życie gospodarcze a ecjnjmika społeczna”. (Vols.2). Lwow: Bibljoteki Polskiego Towarzysiwa Economicznego we Lwowie.

17. Tomanek, F. (1935). Przebudowa życia gospodarczego a rachunkowość (referat wygłoszony na 1-ym regjonalnym zjeżdzie księgowych okręgu Lwowskiego w dniu 1 wrzesnia 1935 r.), Warszawa.

18. Ozeran, A. V. (2012). Doslidzhennya evolyutsiyi buhgalterskoyi (fInansovoyi) zviItnostI na terenah suchasnoyi Ukrayini [Investigation of the evolution of accounting (financial) reporting in the territory of modern Ukraine]. Formuvannya rinkovoyi ekonomiki. [in Ukrainian].

19. Tsyigankov, K. Yu. (2006). Buhgalterskiy balans v istoricheskom razvitii [Balance sheet in historical development] Vserossiyskiy ekonomicheskiy zhurnal. [in Russian].

20. Sokolov, Ya. V. (1999). Bukhgalterskiy uchet: ot istokov do nashikh dney. [Accounting: from the sources to our day]. Moscow: Audit UNITI. [in Russian].

21. Chizhevska, A. V. (2006). Rozvitok buhgalterskogo balansu [Balance sheet development]. Zhytomyr. [in Ukrainian].

22. Sher, I. F. (1925). Buhgalteriya $i$ balans: per. $s$ nem [Accounting and balance] M.: Izd-vo "Ekonomicheskaya zhizn”. [in Russian].

23. Bethge, Y. (2000). Balansovedenie [Balancing; Maintaning balance] V. D. Novodvorskiy (Ed.). Moscow: Bukhhalterskyi uchet Accounting. [in Russian].

24. Petroleum-Industrie-Aktiengesellschaff in Wien Towarzystwo akcijne dla przemyslu naftowego $w$ Wiedniu (1907-1919). Spulka z ograniczonoj odpowiedzialnosci we Lwowiel

25. Stern, R. (1902). Buchhaltungs-Lexikon. Wien und Leipzig.

26. Reisch, R., Kreibig, K. (1907, 1909). Bilanz und Steuer, I Band Wien, II Band Wien.

27. Gorbachevskiy, V. (1946). Kurs buhgalteryi [Accounting course]. [in Ukrainian]. 


\section{O. Lemishovska}

28. Kormosh, T. (1895). Praktichniy pidruchnyk dlya tovarystv zadatkovykh, osnovanih na pidstavi zakonu z dnya 9/IV. 1873 [A Practical Guide for Law Firms Based on the Law of 9 / IV. 1873]. [in Ukrainian].

29. Galle, Ja. (1938). Zarys ksiegowosti kupieckij: dla szkol przysposobienia kupieckiego I stopnia $i$ II klasy gimnazjum kupieckiego. Lwow-Warszawa: Ksiaznica - Atlas S.A.

30. Sciborski, A. (1912). Podręcznik do nauki rachunkowości ogólnej i państwowej. Opracowany wedlug wykladów radcy Dworu Tadeusza KlusikOrzechowskiego na c.k Uniwersytecie we Lwowie: cześć I. Lwów: Drukarnja szcęsnego Bednarskiego we lwowie, nakladem wydawcy.
31. Au, Juliusz. (1899). Nauka rachunkowosci dla potrzeb cospodarstwa wiejskiego zastosowanej. Lwow: I. Zwiazkowa drukarnja we Lwowe.

32. Gorniak, St. (1936). Tematy do ksiegowosti kupieckij: Czesc I. Handel detaliczny: ksiegi szczegolowe inwentrz; Czesc IV. Bilanse; Czese VII. Ewidencja obrotu towarami. Lwow-Warzawa: Ksiaznica-Atlas.

33. Biliansy Kooperatyv prynalezhnykh do Reviziinoho soiuzu Ukrainskykh Kooperatyv u Lvovi, obiednanykh v okruzhnykh oseredkakh Stanyslavskoho voievodstva, (1936). Bezplatnyi dodatok do "HospodarskoKooperatyvnoho Chasopysu”, orhanu Reviziinoho soiuzu Ukrainskykh kooperatyviv u Lvovi. Lviv: drukarnia "Hrafiia". 